\title{
Identification and Characterization of Cancer Stem Cells from Head and Neck Squamous Cell Carcinoma Cell Lines
}

\author{
Valentina Pozzia ${ }^{\mathrm{a}, \mathrm{b}}$ Davide Sartini ${ }^{\mathrm{a}}$ Romina Rocchettic Andrea Santarellia,d Corrado Rubinic \\ Stefano Morgantia Rachela Giuliante ${ }^{a}$ Stefania Calabrese ${ }^{a}$ Giulia Di Ruscio ${ }^{a}$ Fiorenza Orlando \\ Mauro Provincialif Franca Saccuccia Lorenzo Lo Muziog Monica Emanuellia,b \\ aDepartment of Clinical Sciences, Polytechnic University of Marche, Ancona, ${ }^{b} N e w$ York-Marche \\ Structural Biology Center (NY-MaSBiC), Polytechnic University of Marche, Ancona, 'Department of \\ Biomedical Sciences and Public Health, Polytechnic University of Marche, Ancona, 'I.R.C.C.S. I.N.R.C.A., \\ Ancona, ${ }^{e}$ Experimental Animal Models for Aging Units, I.R.C.C.S. I.N.R.C.A, Ancona, ${ }^{\dagger}$ Advanced \\ Technology Center for Aging Research, Scientific Technological Area, I.R.C.C.S. I.N.R.C.A., Ancona, \\ ${ }^{9}$ Department of Clinical and Experimental Medicine, University of Foggia, Foggia, Italy
}

\section{Key Words}

Head and neck squamous cell carcinoma $\cdot$ Cancer stem cells $•$ Nicotinamide $N$-Methyltransferase

\begin{abstract}
Background/Aims: Head and neck squamous cell carcinoma (HNSCC) ranks sixth worldwide for tumor-related mortality. A subpopulation of tumor cells, termed cancer stem cells (CSCs), has the ability to support cancer growth. Therefore, profiling CSC-enriched populations could be a reliable tool to study cancer biology. Methods: We performed phenotypic characterization of 7 HNSCC cell lines and evaluated the presence of CSCs. CSCs from Hep-2 cell line and HNSCC primary cultures were enriched through sphere formation and sphere-forming cells have been characterized both in vitro and in vivo. In addition, we investigated the expression levels of Nicotinamide N-methyltransferase (NNMT), an enzyme overexpressed in several malignancies. Results: CSC markers were markedly expressed in Hep-2 cell line, which was found to be highly tumorigenic. CSC-enriched populations displayed increased expression of CSC markers and a strong capability to form tumors in vivo. We also found an overexpression of CSC markers in tumor formed by CSC-enriched populations. Interestingly, NNMT levels were significantly higher in CSC-enriched populations compared with parental cells. Conclusion: Our study provides an useful procedure for CSC identification and enrichment in HNSCC. Moreover, results obtained seem to suggest that CSCs may represent a promising target for an anticancer therapy.
\end{abstract}

This paper is dedicated to the memory of my husband, Andrea L. Tranquilli (M. Emanuelli) V. Pozzi and D. Sartini contributed equally to the paper.

M. Emanuelli

KARGER 125
Department of Clinical Sciences, Polytechnic University of Marche, via Ranieri 65, Ancona 60131 (Italy)

Tel. +390712204681, Fax +390712204398, E-Mail m.emanuelli@univpm.it 


\section{Cellular Physiology Cell Physiol Biochem 2015;36:784-798 \\ \begin{tabular}{l|l} 
and Biochemistry Published online: May 22, 2015 & $\begin{array}{l}\text { C 2015 S. Karger AG, Basel } \\
\text { www.karger.com/cpb }\end{array}$ \\
\hline
\end{tabular} \\ Pozzi et al: CSC Identification and Characterization in HNSCC}

\section{Introduction}

Head and neck squamous cell carcinoma (HNSCC) is the sixth most common malignancy worldwide, and its incidence is still increasing, particularly in elderly patients since the age of most of the HNSCC patients ranges between 50 and 70 years. Due to delayed diagnosis, HNSCC patients are characterized by poor prognosis (the 5-year relative survival rate of patients with oral cavity and pharynx cancer is about 59\%), high morbidity, and a marked detriment of quality of life [1]. Therefore, there is an urgent need to improve early diagnosis as well as treatment strategies. In fact, despite the advances in the treatment modalities of HNSCC, the overall survival has not improved substantially for the last three decades due to the resistance of cancer cells to conventional radio or chemotherapy $[2,3]$. Therefore, a better understanding of cancer initiation, progression and tumor recurrence is necessary to enable development of more effective therapeutic strategies.

The theory that cancer may be originated and sustained by a small subpopulation of stem-like, self-renewing cells, termed cancer stem cells (CSCs), has gained support in recent years. According to cancer stem cell theory, tumor initiation and maintenance is guaranteed by a subset of undifferentiated cells which have the ability to self-renew and differentiate within a tumor [4-6]. Cancer stem cells are highly tumorigenic, and are considered a major cause of cancer recurrence after conventional therapy due to their increased resistance against radio and chemo-therapeutic modalities [7]. Cancer stem cell theory has fundamental implications for cancer risk assessment, early detection, prognosis, and prevention. Therefore, the development of a reliable model of CSCs becomes crucial for clinical and basic tumor research.

Substantial evidences from recent studies show that many solid tumors contain a subpopulation of CSCs [8-10]. These cells were identified since they express specific cellsurface markers. As concerns stem markers, CD133 was the first to be studied. The human CD133 is a 5-transmembrane glycoprotein which has been used for the identification and isolation of subsets of putative CSCs from several human cancers $[11,12]$. The existence of cancer stem cells was first demonstrated in the context of acute myeloid leukaemia (AML). Surface markers were used to distinguish AML stem cells, which were able to proliferate extensively, from the remaining AML cells, which had limited proliferative potential [13, 14]. Most recently, CSCs were identified in breast cancer where it was found that only a small population of cancer cells were able to induce tumor formation when injected into immunodeficient mice. These cells were found to express CD44, but little or no CD24. In fact, as few as 200 CD44+CD24-/low cancer cells were able to consistently form tumors, whereas injection of thousands of cancer cells that had other phenotypes failed to form cancers. [15, 16]. Further evidence for the existence of CSCs occurring in solid cancers has been found in the central nervous system (CNS) malignancies where, a subpopulation of cells expressing the human neural stem-cell marker CD133 accounted for almost all in vitro proliferative activity. In culture, these CD133 + cells gave rise to cells that expressed neuronal and/or glial markers in proportions that mirrored the phenotypes of cells within the original cancers [17]. Moreover, it has been demonstrated that glioblastoma cells expressing CD133 were resistant to ionizing radiations because they were very efficient at inducing the repair of damaged DNA [18]. The identification of these cells provided evidence that, within a tumor, a hierarchical system exists, being cancer stem cells at the top. Since then, CSCs have been identified in several other malignancies, including lung, prostate, colorectal, pancreas, liver and recently HNSCC [19-26]. The identification of CSCs in different kinds of cancer has revealed that CSCs are largely tissue specific and that universal CSC marker is unlikely. While a lot of studies have identified CSC markers across a variety of solid cancers, relatively few of these markers have been studied in head and neck squamous cell carcinoma. Several studies have examined the cell-surface marker CD133 in HNSCC. CD133 has been suggested as a potential marker of CSCs in a human laryngeal tumor cell line. In this cell line, only a small percentage of cells expressed CD133 marker and, in comparison with CD133(-) tumor cells, CD133(+) cells possessed a marked capacity for tumor formation in vivo. Moreover, a small 


\section{Cellular Physiology Cell Physiol Biochem 2015;36:784-798 \\ \begin{tabular}{l|l|l}
\hline DOI: 10.1159/000430138 & (C) 2015 S. Karger AG, Basel
\end{tabular} \\ \begin{tabular}{l|l|} 
and Biochemistry Published online: May 22, 2015 & www.karger.com/cpb \\
\hline
\end{tabular} \\ Pozzi et al: CSC Identification and Characterization in HNSCC}

population (1-2\%) of CD133+ cells was identified in oral squamous cell carcinoma (OSCC) cell lines and tissues. These CD133+ cells possessed increased clonogenicity, invasiveness, and in vivo tumorigenicity compared to CD133- counterparts [27, 28]. In addition, a previous report has demonstrated that a subpopulation of CD44+ cells, isolated from HNSCC specimens by fluorescence activated cell sorting (FACS) analysis, possessed the unique properties of CSCs [26]. The formation of CSCs may be related to alterations in signal transduction inside the cell and in cell-cell interactions.

Development of new therapies that target these CSCs could significantly improve the clinical treatment of tumor. Therefore, it is fundamental to identify, within cancer, the subpopulation of cells that display CSCs properties. Recent studies have suggested that CSCs can be enriched from many solid tumors or cancer cells by sphere body formation under serum-free medium cultivation, whereby the serum-free condition helps maintain the CSCs undifferentiated [29-31].

In the present study, we reported the identification of sphere-forming cells from Hep2 cell line and HNSCC primary cultures, and the characterization of their CSCs properties. We have used a modified culture system to enrich CSCs through sphere formation, by cultivating Hep-2 cells and cells derived from HNSCC primary cultures in defined serumfree medium with specific growth factors. Subsequently, we analyzed whether these CSCsenriched populations possessed distinct properties of cancer stem-like cells, by evaluating the expression of specific stem cell markers. The tumorigenic potential of CSC-enriched population from Hep-2 cells was evaluated in vivo by subcutaneous injection into athymic mice. In addition, we investigated the mRNA expression and catalytic activity levels of Nicotinamide N-Methyltransferase (NNMT), an enzyme involved in the biotransformation of many xenobiotics, that was found overexpressed in several malignancies.

\section{Materials and Methods}

\section{Cell culture}

Human HNSCC cell lines (Hep-2, PE/CA-PJ34, PE/CA-PJ46, PE/CA-PJ49, Ca 9-22, HSC-2, HSC3), purchased from the American type Culture Collection (ATCC, Rockville, MD, USA), were cultured in DMEM/F12 (Hep-2, PE/CA-PJ34, PE/CA-PJ46, PE/CA-PJ49, Ca 9-22) or RPMI 1640 (HSC-2, HSC-3) media supplemented with $10 \%$ fetal bovine serum, $100 \mathrm{U} / \mathrm{ml}$ of penicillin, $100 \mu \mathrm{g} / \mathrm{ml}$ of streptomycin at $37^{\circ} \mathrm{C}$ in a humidified $5 \% \mathrm{CO}_{2}$ incubator. Table 1 reports the site of origin of each HNSCC cell line.

\section{Primary culture}

Human tissue specimens of head and neck carcinomas were obtained during the standard surgical procedure by the Department of Biomedical Sciences and Public Health section of Pathology (Polytechnic University of Marche), after consent was obtained for diagnostic purposes. After diagnostic analysis, the residual amount was used to generate primary cancer cell cultures. No consent was given for our experimental research since the data were analyzed anonymously.

The authors did not participate in sample collection and had no access to any identifying patient information prior to anonymization. Briefly, tissue specimens were transported in sterile saline and processed immediately after excision. Primary tumor samples were rinsed in DMEM/F12 medium with gentamicin $(50 \mu \mathrm{g} / \mathrm{ml})$
Table 1. Origin of HNSCC cell lines and primary cultures. *Hep-2 cells are derived via HeLa contamination

\begin{tabular}{ll}
\hline Cell line or primary culture & Tissue or organ \\
\hline Hep-2 & Larynx* \\
PE/CA-PJ34 & Oral cavity \\
PE/CA-PJ46 & Oral cavity \\
PE/CA-PJ49 & Oral cavity (tongue) \\
Ca 9-22 & Oral cavity (gingiva) \\
HSC-2 & Oral cavity \\
HSC-3 & Oral cavity (tongue) \\
Primary culture 1 & Oral cavity (tongue) \\
Primary culture 2 & Oral cavity (gingiva) \\
Primary culture 3 & Oral cavity (tongue) \\
Primary culture 4 & Oral cavity (tongue) \\
Primary culture 5 & Oral cavity (lip) \\
\hline
\end{tabular}




\section{Cellular Physiology Cell Physiol Biochem 2015;36:784-798 \begin{tabular}{l|l} 
and Biochemisty $\begin{array}{l}\text { DOI: 10.1159/000430138 } \\
\text { Published online: May 22, } 2015\end{array}$ & $\begin{array}{l}\text { C 2015 S. Karger AG, Basel } \\
\text { www.karger.com/cpb }\end{array}$ \\
\hline
\end{tabular} \\ Pozzi et al: CSC Identification and Characterization in HNSCC}

and amphotericin B (50 $\mathrm{\mu g} / \mathrm{ml})$ to minimize the risk of microbial contamination. After rinsing, tissues were carefully minced into small pieces and distributed in T25 flasks. To enable the samples to adhere to the flask surface, tissues were incubated at $37^{\circ} \mathrm{C}$ for $1 \mathrm{~h}$ prior to adding medium. After 3-4 days of incubation, some of the fragments and cells adhered to the flask. HNSCC cell growth was observed a week after primary culture initiation. Fibroblasts were removed by brief exposure to $0.25 \%$ trypsin-EDTA (Invitrogen, Buffalo). Primary cancer cell cultures were obtained after continuous successful passage of HNSCC cells and elimination of fibroblast-like cells. Table 1 reports the site of origin of each HNSCC primary culture.

\section{Sphere formation assay}

For sphere-forming culture, HNSCC cells, from Hep-2 cell line or primary culture of HNSCC specimens, were plated at a density of $1 \times 10^{5}$ cells/well in 6-well ultra-low attachment plates in serum-free DMEM/ F12 medium supplemented with human recombinant epidermal growth factor (EGF; $10 \mathrm{ng} / \mathrm{ml}$ ) and basic fibroblast growth factor (bFGF; $20 \mathrm{ng} / \mathrm{ml}$ ). Fresh aliquots of EGF and bFGF were added every 2 days, and the serum-free medium was changed every other day until the sphere formation.

\section{Cell viability assay}

Trypan blue exclusion test was performed to assess the cell viability. HNSCC cell lines were cultured on 24-well plates at a density of $2 \times 10^{4}$ cells/well. After trypsinization, the cells were counted with a hemocytometer in a 1:1 dilution of cells in a 0.4\% trypan blue solution (Euroclone) under the microscope. The cell viability was quantified by counting the viable (non-stained) and dead (stained) cells at various time points $(0,24,48$ and $72 \mathrm{~h})$. The experiment was repeated three times. The mean value of tests was presented as the final result.

Immunocytochemistry

Immunocytochemical analysis was performed against CD133 and CD44 proteins. Cells were seeded in 24-well plates $\left(1 \times 10^{5}\right.$ cells/well) containing one coverslip per well. After $24 \mathrm{~h}$, cells attached to the coverslips were washed with PBS and fixed with 4\% paraformaldehyde in PBS solution for 10 min. The cells were then permeabilized with $0.1 \%$ Triton X-100 in PBS for $10 \mathrm{~min}$ at room temperature. After washing with PBS, cells were immersed in a blocking solution for $1 \mathrm{~h}$ at room temperature. Cells were then incubated at $4^{\circ} \mathrm{C}$ overnight with a mouse antibody (IgG1) for human CD133/1 (1:50, Miltenyi), and a rabbit antibody (IgG) for human CD44 (1:60, Abcam). After rinsing in PBS, cells were incubated with biotinylated secondary antibodies (Calbiochem) for $1 \mathrm{~h}$ at room temperature, followed by treatment with avidin-biotin complex (Vectastain ABC, Vector Laboratories) according to the manufacturer's instructions. Peroxidase activity was visualized by $5 \mathrm{~min}$ of incubation with diaminobenzidine (DAB) (Vector Laboratories), and then slides were counterstained with hematoxylin, and mounted. The cells were observed under light microscope.

\section{RNA extraction}

Cells $\left(1 \times 10^{6}\right)$ or tissue samples (30-40 mg) were homogenized in a lysis buffer, and total RNA was extracted through the SV Total RNA Isolation System (Promega, Madison, WI, USA), according to the manufacturer's protocol. The quantity and quality of RNA were assessed spectrophotometrically at $260 \mathrm{~nm}$ and $280 \mathrm{~nm}$, and confirmed by electrophoresis on denaturated $1 \%$ agarose gel. Total RNA ( $2 \mu \mathrm{g})$ was reverse transcribed in a total volume of $25 \mu \mathrm{l}$ for 60 minutes at $42^{\circ} \mathrm{C}$ with M-MLV Reverse Transcriptase (Promega, Madison, WI, USA) using random nonamers.

\section{Real-Time quantitative PCR}

To examine putative stem cell markers or NNMT mRNA expression quantitatively, a Real-Time PCR assay was performed using a CFX96 Real-Time PCR Detection System (Bio-Rad Laboratories, Hercules, CA, USA). cDNA, generated as described above, was used as template. To avoid false-positive results due to amplification of contaminating genomic DNA in the cDNA preparation, all primers were selected to flank an intron, and PCR efficiency was tested for both primer pairs and found to be close to 1 . The sequences of specific primers used were reported in Table 2 .

Genes were run in duplicate for 40 cycles at $94^{\circ} \mathrm{C}$ for 30 seconds and $58^{\circ} \mathrm{C}$ for 30 seconds, using SsoFast EvaGreen Supermix (Bio-Rad). All samples were tested in triplicate with the reference gene $\beta$-actin for data normalization to correct for variations in RNA quality and quantity. Direct detection of PCR 


\section{Cellular Physiology Cell Physiol Biochem 2015;36:784-798 \begin{tabular}{l|l} 
and Biochemistry $\begin{array}{l}\text { DOI 10.1159/000430138 } \\
\text { Published online: May 22, 2015 }\end{array}$ & $\begin{array}{l}\text { C 2015 S. Karger AG, Basel } \\
\text { www.karger.com/cpb }\end{array}$ \\
\hline
\end{tabular} \\ Pozzi et al: CSC Identification and Characterization in HNSCC}

products was monitored by measuring the fluorescence produced by EvaGreen dye binding to double strand DNA after every cycle. These measurements were then plotted against cycle numbers. The parameter threshold cycle (Ct) was defined as the cycle number at which the first detectable increase above the threshold in fluorescence was observed. Stem cell markers (CD133, CD44, Oct4, Sox2, Nanog and Nestin), and NNMT differential expression was calculated by using the $\Delta \mathrm{Ct}$, where $\Delta \mathrm{Ct}=$ $\mathrm{Ct}$ (gene of interest) - Ct ( $\beta$-actin). Fold changes in relative gene expression were calculated by $2^{-\Delta(\Delta \mathrm{Ct})}$ where $\Delta(\Delta \mathrm{Ct})$ $=\Delta \mathrm{Ct}$ (CSC-enriched populations) $-\Delta \mathrm{Ct}$ (parental cells).
Table 2. Primers used for quantitative Real-Time PCR

\begin{tabular}{|c|c|}
\hline Target gene & Sequence \\
\hline CD133 & $\begin{array}{l}\text { forward 5'-TGCTGCTTGTGGAATAGACAGAATG-3' } \\
\text { reverse 5'-AGGAAGGACTCGTTGCTGGTGAA-3' }\end{array}$ \\
\hline CD44 & $\begin{array}{l}\text { forward 5'-CGGACACCATGGACAAGTTT-3' } \\
\text { reverse 5'-GAAAGCCTTGCAGAGGTCAG-3' }\end{array}$ \\
\hline Nestin & $\begin{array}{l}\text { forward 5'-CAGCTGGCGCACCTCAAGATG-3' } \\
\text { reverse 5'-AGGGAAGTTGGGCTCAGGACTGG-3' }\end{array}$ \\
\hline Oct4 & $\begin{array}{l}\text { forward 5'-CTTGCTGCAGAAGTGGGTGGAGGAA-3' } \\
\text { reverse 5'-CTGCAGTGTGGGTTTCGGGCA-3' }\end{array}$ \\
\hline Nanog & $\begin{array}{l}\text { forward 5'-GATTTGTGGGCCTGAAGAAA-3' } \\
\text { reverse 5'-AAGTGGGTTGTTTGCCTTTG-3' }\end{array}$ \\
\hline Sox2 & $\begin{array}{l}\text { forward 5'-ACTTTTGTCGGAGACGGAGA-3' } \\
\text { reverse 5'-CATGAGCGTCTTGGTTTTCC-3' }\end{array}$ \\
\hline NNMT & $\begin{array}{l}\text { forward 5'-GAATCAGGCTTCACCTCCAA-3' } \\
\text { reverse 5'-TCACACCGTCTAGGCAGAAT-3' }\end{array}$ \\
\hline$\beta$-actin & $\begin{array}{l}\text { forward 5'-TCCTTCCCTGGGCATGGAGT-3' } \\
\text { reverse 5'-AGCACTGTGTTGGCGTACAG-3' }\end{array}$ \\
\hline
\end{tabular}

\section{NNMT enzyme activity}

An HPLC-based catalytic assay was performed to analyse NNMT activity in CSC-enriched populations and parental cells. A frozen cell pellet $\left(5 \times 10^{6}\right.$ cells $)$ was suspended in $200 \mu$ lof cold lysis buffer $(50 \mathrm{mM}$ tris$\mathrm{HCl}$, pH 8.6, $2 \mu \mathrm{g} / \mathrm{ml}$ aprotinin, $1 \mathrm{mM}$ phenylmethylsulfonyl fluoride, $1 \mathrm{mM}$ dithiothreitol, 1\% Nonidet P40) and $1 / 2$ vol glass beads. The suspension was vortexed at maximum speed for 2 minutes and then chilled on ice for 2 minutes. The homogenate was centrifuged at $16000 \mathrm{xg}$ for 10 minutes at $4^{\circ} \mathrm{C}$. The supernatant was kept at $4^{\circ} \mathrm{C}$ until assayed. The standard assay mixture contained $50 \mathrm{mM}$ tris- $\mathrm{HCl}, \mathrm{pH}$ 8.6, $1 \mathrm{mM}$ dithiothreitol, $5 \mathrm{mM}$ nicotinamide, $0.5 \mathrm{mM} \mathrm{S}$-adenosyl-L-methionine and the appropriate amount of enzyme sample to a reach final volume of $350 \mu$. The reaction was started by adding the substrate S-adenosyl-L-methionine. Incubations were performed at $37^{\circ} \mathrm{C}$ for 30 and 60 minutes. The reaction was stopped by adding $100 \mu \mathrm{l}$ assay mixture to $50 \mu \mathrm{l}$ ice-cold $1.2 \mathrm{M} \mathrm{HClO}_{4}$. After 10 minutes at $0^{\circ} \mathrm{C}$ proteins were removed by 1 minute of centrifugation in a microfuge and $130 \mu \mathrm{l}$ perchloric acid supernatant were then neutralized by adding 35 $\mu \mathrm{l} 0.8 \mathrm{M} \mathrm{K}_{2} \mathrm{CO}_{3}$. The $\mathrm{KClO}_{4}$ so formed was removed by centrifugation. $100 \mu \mathrm{l}$ of the neutralized supernatant was injected into a high performance liquid chromatography system 10 Dvp-uv-vis photodiode array detector (Shimadzu, Duisburg, Germany) using a 250 x 4.6 mm inner diameter Supelcosil@ LC-18 $5 \mu \mathrm{m}$ reversed phase column. Elution conditions were as previously described [32]. Enzyme activities were tested by measuring the amount of N1-methylnicotinamide produced, as determined by the peak areas of the separated compound with $1 \mathrm{U}$ activity representing the formation of $1 \mathrm{nmol} \mathrm{N} 1$ - methylnicotinamide per hour of incubation at $37^{\circ} \mathrm{C}$.

\section{Animals}

Six- to eight-week-old male and female athymic BALB/c nude (nu/nu) mice (average weight $30 \mathrm{~g}$ ) were selected for this study. Mice (Harlan Laboratories, Udine, Italy) were housed in plastic cages and fed with food pellets and water ad libitum. The animals were maintained at constant temperature $\left(20 \pm 1^{\circ} \mathrm{C}\right)$ and humidity (50 $\pm 5 \%$ ) on a 12-h light/12-h dark cycle.

The procedure and facilities complied with ethical standards and followed the requirements of Commission Directive 86/609/EEC concerning the protection of animals used for experimental and other scientific purposes. Italian legislation is defined in D.L. No. 116 of 27 January 1992. The experimental protocols were also approved by the Institutional Animal Care Committee of the Ministry of Health, Italy. All experiments were performed according to the Principles of Laboratory Animal Care. All efforts were made to minimize animal suffering and to reduce the number of animals used.

Tumorigenicity assay

Tumorigenic capacity of the 7 HNSCC cell lines was assessed by subcutaneous injection of cells into $\mathrm{BALB} / \mathrm{c}$ nude mice, which were maintained under pathogen-free conditions. Mice were divided into seven 


\section{Cellular Physiology Cell Physiol Biochem 2015;36:784-798 \\ \begin{tabular}{l|l|l} 
DOI: 10.1159/000430138 & (C) 2015 S. Karger AG, Basel
\end{tabular} \\ \begin{tabular}{l|l|l|l|l|l} 
and Biochemistry Published online: May 22, 2015 & www.karger.com/cpb \\
\cline { 1 - 2 }
\end{tabular} \\ Pozzi et al: CSC Identification and Characterization in HNSCC}

experimental groups ( 5 animals for each group). Each cell line $\left(2 \times 10^{6}\right.$ cells/mouse) was resuspended in 200 $\mu \mathrm{l}$ PBS 1X/Matrigel mixture (BD Biosciences, Bedford, MA, USA) at a 1:1 ratio to support initial tumor growth, and cells were inoculated subcutaneously on the left and right backs of mice. Tumor size was measured weekly with a caliper and tumor volume was calculated using the formula volume $=$ length $\mathrm{x}$ width $\mathrm{x}$ height. After 8 weeks, all of the mice were euthanized with excess $\mathrm{CO}_{2}$, and tumor formation was assessed. The masses were dissected and samples were harvested for histological examination. For histology, tumors were fixed with 4\% paraformaldehyde in PBS solution, and paraffin-embedded sections were prepared following routine procedures. Subsequently, the tumorigenic potential of CSC-enriched populations from Hep-2 cell line was also evaluated. Mice were divided into two experimental groups (10 animals for each group), and Hep- 2 cells and CSC-enriched populations $\left(2.5 \times 10^{5}\right.$ cells/mouse $)$ were inoculated subcutaneously on the left and right backs of each mouse. Tumor size was measured weekly with a caliper and, after 8 weeks, all of the mice were euthanized with excess $\mathrm{CO}_{2}$. Tumor samples obtained after injection of parental and CSC-enriched cells have been both snap-frozen in liquid nitrogen and paraffin-embedded. Frozen samples were analyzed for cancer stem cell markers expression by Real-Time PCR, as previously described for cells. Histological and immunohistochemical analyses were performed on paraffined samples.

Immunohistochemistry

Immunohistochemical analysis was performed against CD133 and CD44 proteins. The $4 \mu \mathrm{m}$ thick histological sections were mounted on glass slides, deparaffinized in xylene, rehydrated in ethanol and microwave-heated in sodium citrate buffer $(10 \mathrm{mM}, \mathrm{pH}$ 6) for antigen retrieval. Then, endogenous peroxidase was blocked by incubation with $3 \%$ hydrogen peroxide for $7 \mathrm{~min}$. The sections were washed for $5 \mathrm{~min}$ with PBS and incubated with the primary antibody for $1 \mathrm{~h}$ at $37^{\circ} \mathrm{C}$. The primary antibodies used were a mouse antibody (IgG1) for human CD133/1 (1:50, Miltenyi), and a rabbit antibody (IgG) for human CD44 (1:60, Abcam). After washing with PBS, the sections were incubated with the EnVision HRP detection system for $30 \mathrm{~min}$ at room temperature. After being washed with water, the signal was detected using 3,3'-diaminobenzidine (DAB). The counterstaining was performed using Hematoxylin, and then the sections were dehydrated in ethanol, clarified and mounted. All slides were observed with light microscopy.

\section{Statistical analysis}

Data were analyzed using GraphPad Prism software version 6.00 for Windows (GraphPad Prism Software, San Diego, CA,USA). Values were expressed as mean \pm s.d. Differences between groups were determined by repeated measures ANOVA. A $p$ value $<0.05$ was accepted as statistically significant.

\section{Results}

Characterization of HNSCC cell lines in vitro and in vivo

Phenotypic characterization of 7 HNSCC cell lines was performed by evaluating replication rate and tumorigenic potential, in vitro and in vivo, respectively. Replication rate was monitored by plating cells in 24 wells plate and counting them by trypan blue exclusion assay at various time points $(0,24,48$ and $72 \mathrm{~h})$. As shown in Figure 1, Hep-2 cell line had a more marked proliferative activity compared to the other cells. Moreover, Hep-2 cells possessed a greater tumorigenic ability in vivo (Fig. 2). Immunocytochemical analysis revealed that about 1.0-2.0\% of CD133+ and CD44+ cells existed in all HNSCC cell lines tested. In particular, Hep- 2 contained 5\% CD133+ cells and 3\% CD44+ cells (data not shown).

Sphere formation from Hep-2 cell line and primary HNSCC cultures

A subpopulation of CSCs from Hep-2 cell line or primary HNSCC culture was enriched through sphere formation. Cells were cultured in DMEM/F12 serum free medium with bFGF and EGF. After being in culture for 3 weeks, cancer cells gradually started to detach from culture plates, aggregate and form sphere-like bodies. Increase of the volume of sphere-like body was observed with longer cultivation ( 6 weeks). The sphere formation from primary HNSCC culture was faster than that of sphere from Hep-2 cells. In fact, the primary culture cells isolated from HNSCC tumour samples formed sphere-like bodies in 2-3 weeks of culture (Fig. 3). 
Fig. 1. Cell viability assay. The cell viability of HNSCC cell lines was determined by trypan blue exclusion assay at various time points $(24,48$ and $72 \mathrm{~h}$ ). Data are presented as the mean \pm s.d.

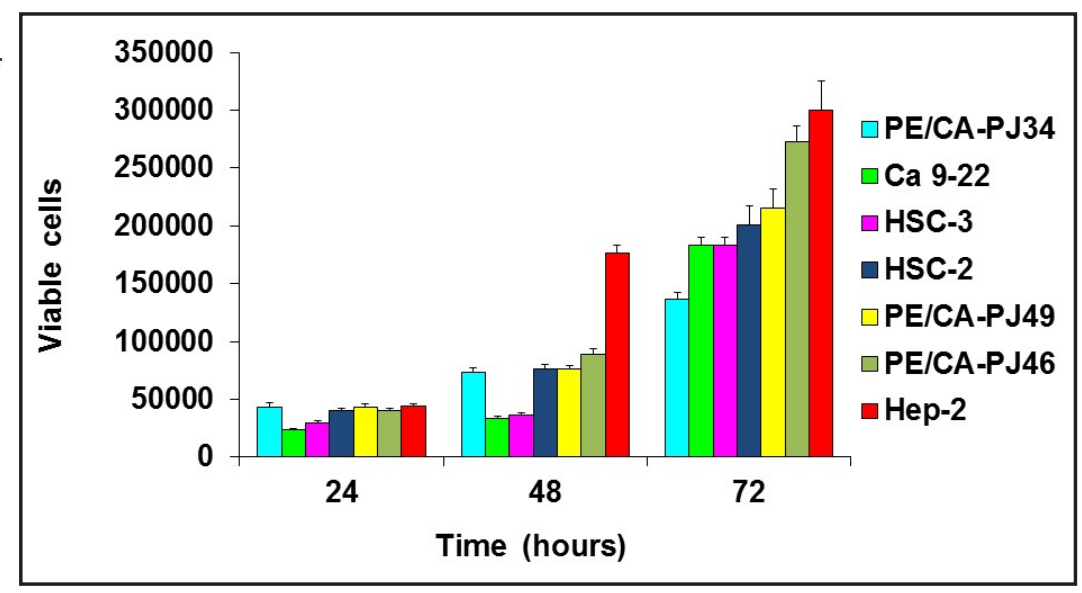

Fig. 2. In vivo tumorigenicity assay. Tumorigenic capacity of 7 HNSCC cell lines was assessed by subcutaneous injection of cells into BALB/c nude mice. The tumor size was measured with a caliper weekly and tumor volume was then calculated. Within each group, volumes are expressed as mean \pm s.d.

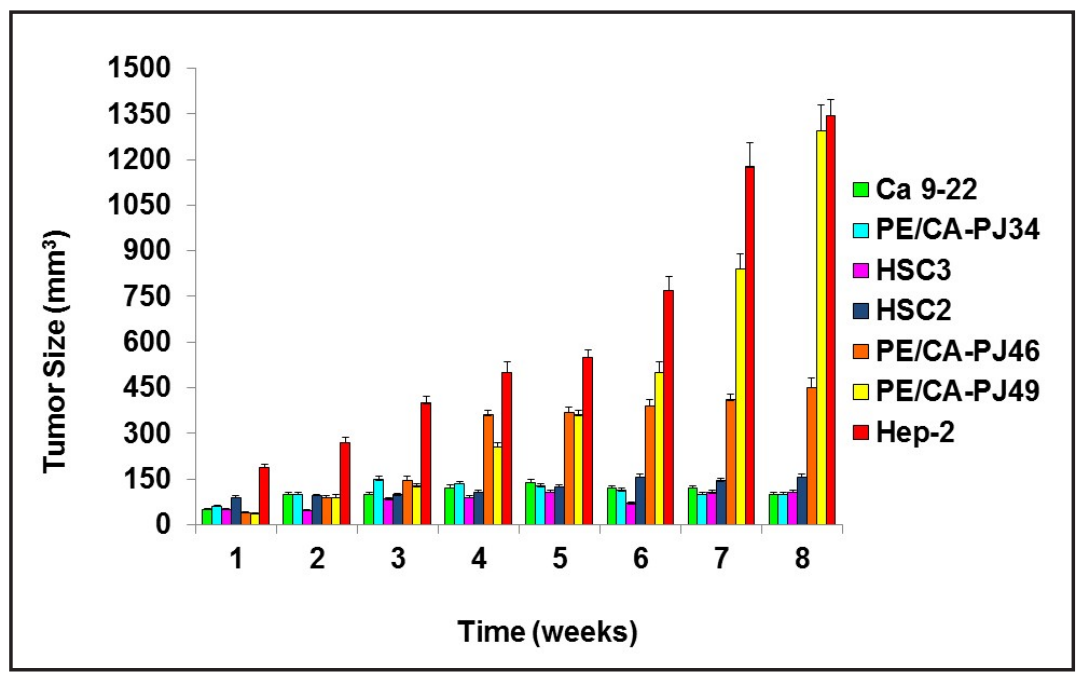

Fig. 3. The sphere formation from Hep-2 cell line and HNSCC primary culture. CSC-enriched populations from Hep-2 cell line (A) or primary culture (B), but not parental cells cultivated under standard conditions, were able to form spheres in suspension (10x magnification).

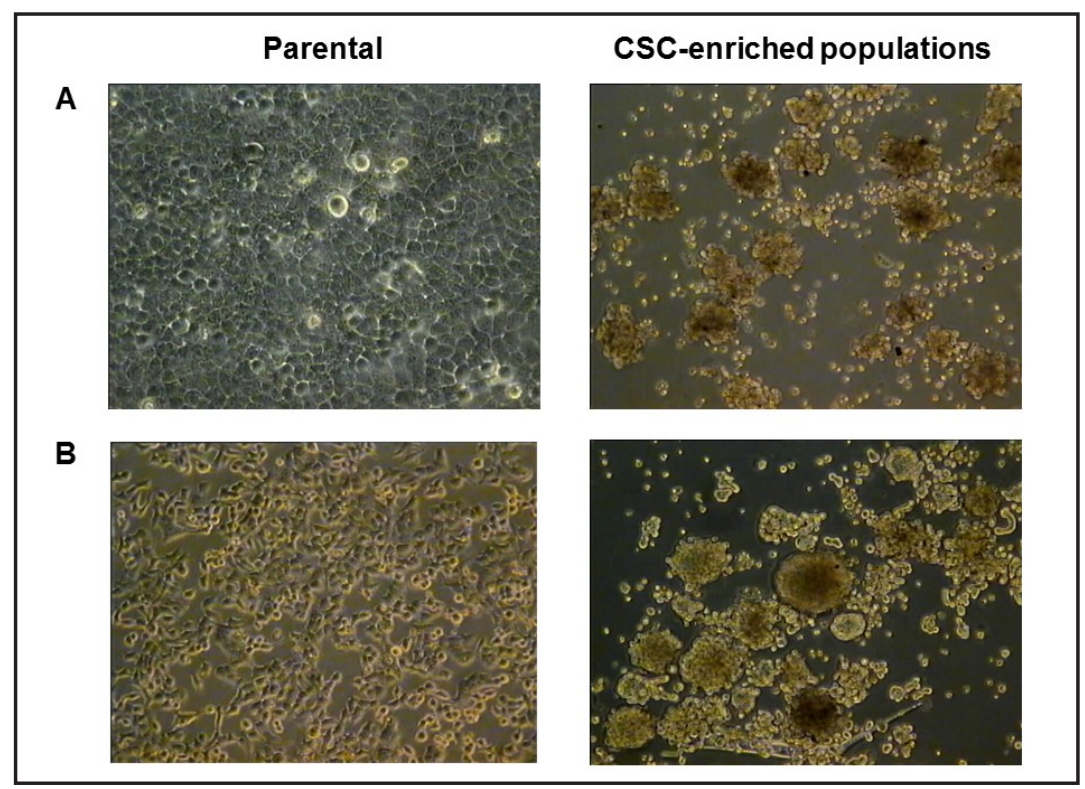

Stem cell marker expression in CSC-enriched subpopulations

Expression profiling of stem cell-specific genes and related proteins, in parental cells and CSC-enriched populations derived from Hep-2 cells or HNSCC primary culture was 
Fig. 4. Stem cell marker expression in CSC-enriched populations. Real-time PCR analysis showed mRNA expression level of putative stem cell markers in CSC-enriched populations compared with parental cells obtained from Hep-2 cell line (A) or primary cultures (B).

evaluated. Real-Time PCR analysis revealed that the mRNA expression levels of a number of stem cell markers including CD133, CD44, Oct4, Sox2, Nanog, and Nestin were significantly higher in CSC-enriched subpopulations compared to the parental counterpart (Fig. 4A and B). Immunocytochemical analysis confirmed the increased expression of CD133 and CD44 in CSC-enriched populations compared with parental cells (Fig. 5).

NNMT expression analysis and enzyme activity assay in Hep-2 cell line

To examine NNMT expression quantitatively, cellular samples were analyzed by Real-Time PCR. As shown in Table 3, NNMT expression was

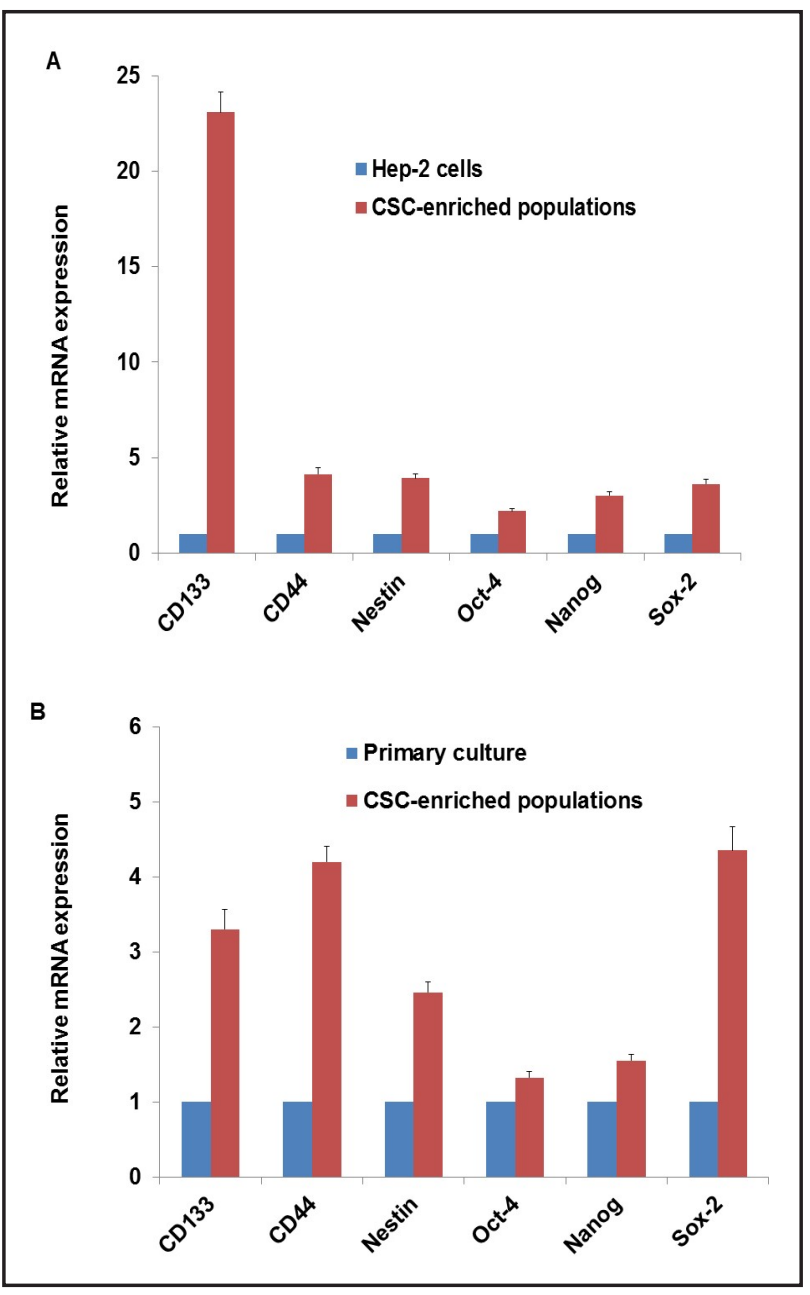

1.8-fold higher in CSCs enriched-populations compared with the parental counterpart. To confirm the above-reported results, a HPLC-based catalytic assay was performed to analyze NNMT activity in CSC-enriched populations. In keeping with the results of Real-Time PCR, the level of NNMT specific activity was higher in CSC-enriched populations $(6.17 \mathrm{U} / \mathrm{mg})$ compared to the value measured in parental cells $(2.79 \mathrm{U} / \mathrm{mg})$.

\section{In vivo tumorigenicity of CSC-enriched populations}

Tumor formation potential of CSC-enriched subpopulations was investigated in vivo. Hep- 2 cells and CSC-enriched populations were subcutaneously injected $\left(2.5 \times 10^{5} \mathrm{cells} /\right.$ mouse) on the left and right backs of athymic BALB/c nu/nu mice (10 mice/group) and tumor growth was monitored weekly. After 8 weeks, the mean size of tumors developed in mice injected with CSC-enriched populations $\left(6900 \pm 400 \mathrm{~mm}^{3}\right)$ was significantly different $(p<0.05)$ compared with that in mice injected with parental cells $\left(980 \pm 72 \mathrm{~mm}^{3}\right)$ (Fig. 6). In particular, as shown in Figure 7 CSC-enriched populations yielded tumors of a much larger size compared with the tumors generated by parental cells, suggesting that CSC-enriched populations had a stronger ability to form tumors in vivo compared to the parental cell line. At 8 weeks after inoculation all mice were then sacrificed, and tumor samples obtained after injection of parental and CSC-enriched cells were both snap-frozen in liquid nitrogen and paraffin-embedded. Frozen samples were analyzed by Real-Time PCR, while histological and immunohistochemical analyses were performed on formalin-fixed and paraffin-embedded samples. Interestingly, Real-Time PCR analysis showed an overexpression of stem cell markers on tumor formed by CSC-enriched populations compared with tumor observed after injection of parental cells (Fig. 8). In keeping with the results of Real-Time PCR, 
Table 3. NNMT expression in Hep-2 cell line

\begin{tabular}{lcc}
\hline & Relative NNMT mRNA expression & NNMT specific activity (U/mg) \\
\hline Parental Cells & 1 & 2.79 \\
CSC-enriched populations & 1.8 & 6.17 \\
\hline
\end{tabular}

Fig. 5. Immunocytochemistry. Representative images of CD133 (top) and CD44 (bottom) immunocytochemical staining in parental and CSC-enriched populations from Hep-2 cells (25x magnification).

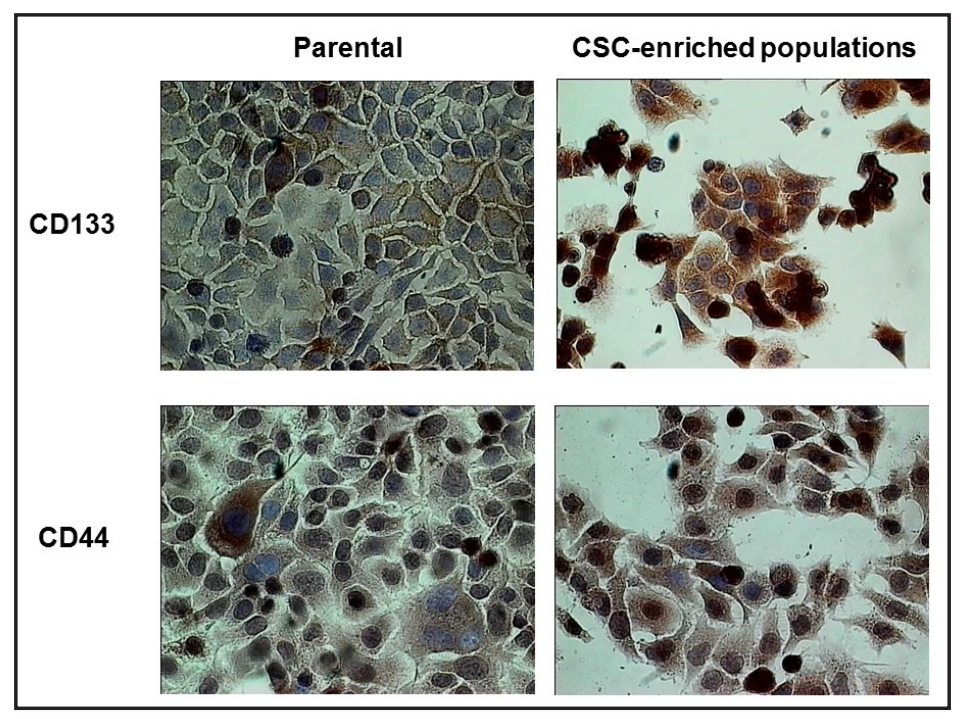

Fig. 6. Time course of tumour growth. Tumorigenic potential of CSC-enriched populations from Hep-2 cells was assessed by subcutaneous injection into BALB/c nude mice. The tumour size was measured with caliper weekly and the tumour volume was calculated. After 8 weeks, mice inoculated with CSCenriched populations showed a significant increase $\left.C^{*}, \mathrm{p}<0.05\right)$ in tumour growth compared with mice inoculated with parental cells. Data are expressed as mean \pm s.d.
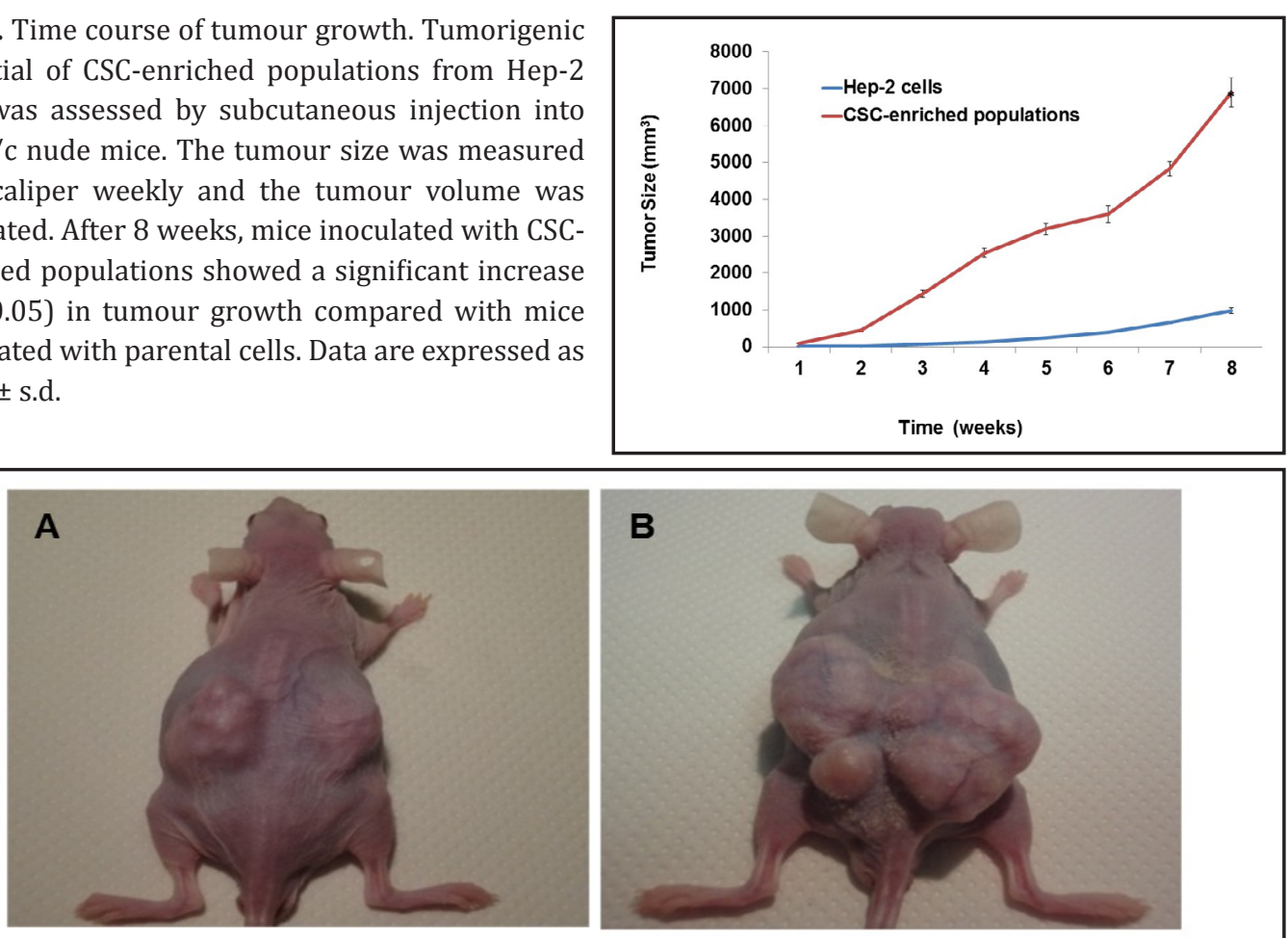

Fig. 7. In vivo tumorigenicity of CSC-enriched populations. In vivo tumour formation potential of parental cells and CSC-enriched populations from Hep-2 cell line. Representative photos showing BALB/c nude mice injected subcutaneously, in the right and left flank, with Hep-2 parental cells (A) and CSC-enriched populations (B).

immunohistochemical analysis showed significantly increased positive signals for CD133 (25\% vs $5 \%$ ) and CD44 (15\% vs 1-2\%) in tumors derived from the injection of CSC-enriched KARGER 
Fig. 8. Real-time PCR analysis of putative stem cell markers. Realtime PCR analysis showed an overexpression of stem cell markers on tumor formed by CSC-enriched populations compared with tumor observed after injection of parental cells.

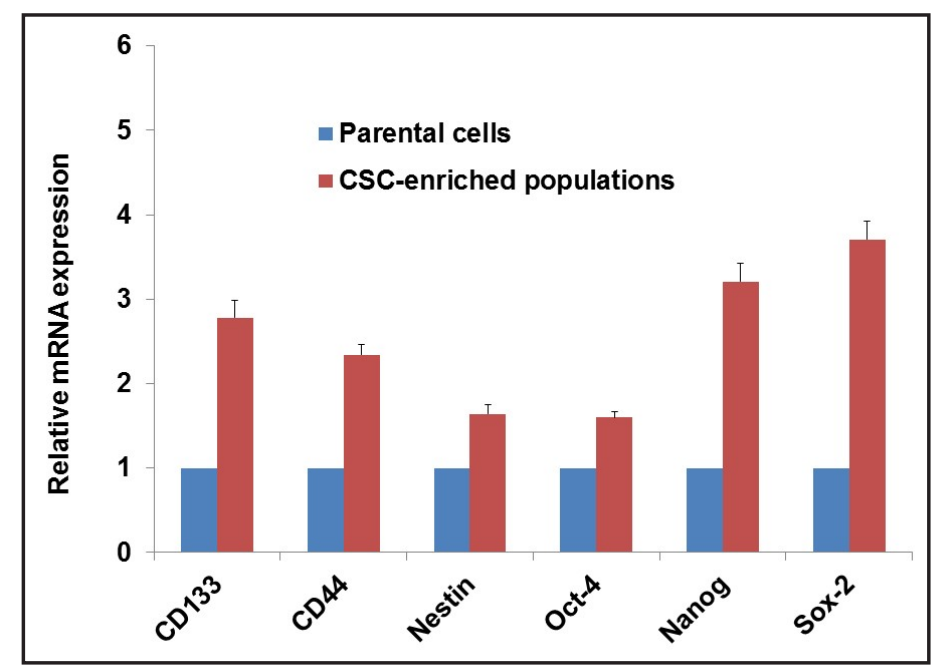

subpopulations as compared with tumors formed after injection of parental cells (data not shown). Moreover, a histological examination confirmed the epithelial histogenesis of the tumor in agreement with the cell line inoculated, excluding the formation of the primary tumor. These results suggested the involvement of CSC-enriched populations in cancer development.

\section{Discussion}

Head and neck squamous cell carcinoma is one of the world's most common tumors, with estimated 500,000 new cases diagnosed each year [33]. Local invasion and regional lymph node metastases, together with relative resistance to conventional chemo and radiotherapy, lead to an unfavourable outcome [34]. Despite increased experience in surgical technology and adjuvant therapies, the overall prognosis of HNSCC remain unimproved, resulting in the urgent need for novel treatment strategies [35]. A better understanding of the molecular genetics of HNSCC could reveal the mechanisms of the initiation and progression of this malignancy, and help to find a new way to develop therapeutic strategies.

In recent years, several studies have led to the discovery that many cancers appear to be supported by cells with stem-like properties. According to cancer stem cell theory, tumor development would be guaranteed by a distinct subpopulation of tumor cells, termed cancer stem cells (CSCs), that have the ability to self-renew and to resist to chemotherapeutic agents, preventing the elimination of cancer $[36,37]$. These cells appear to play a major role in cancer recurrence and metastatic spread, common causes of the high morbidity and death of the majority of patients with HNSCC. Therefore, the identification and the targeted elimination of these CSCs has been considered fundamental for cancer treatment [38].

CSCs have been isolated from many tumors, such as acute myeloid leukemia, breast, brain, lung, prostate, colorectal, pancreatic, liver and ovarian cancers $[13,15,19-25,39,40]$. Both SCs [41] and CSCs were identified since they were found to express specific cell-surface markers. A lot of studies have identified CSC markers across a variety of solid cancers, but relatively few of these markers have been studied in HNSCC, and the putative CSCs from HNSCC have not been well characterized [42-44]. At present, the identification of CSCs in HNSCC is obstacled by the lack of well-validated markers characterizing this cell lineage, and isolation of CSCs through putative stem cell markers (such as CD133, CD44) must be performed through precise and innovative technologies. Concurrent studies have suggested that CSCs can be enriched in spheres when these cells are cultured in serum-free medium supplemented with specific growth factors [30,31]. 


\section{Cellular Physiology Cell Physiol Biochem 2015;36:784-798 \\ \begin{tabular}{l|l} 
and Biochemistry Published online: May 22, 2015 & $\begin{array}{l}\text { C) 2015 S. Karger AG, Basel } \\
\text { www.karger.com/cpb }\end{array}$ \\
\hline
\end{tabular} \\ Pozzi et al: CSC Identification and Characterization in HNSCC}

In the present study, we used a modified culture system to identify and enrich CSCs from HNSCC primary cultures and cancer cell lines with sphere formation, and we further investigated their properties using molecular and phenotypic characterization. Seven HNSCC commercial cell lines were analyzed in order to identify and isolate CSC subclones. We evaluated replication rate by cell number counting and tumorigenic potential by analysis in vivo, and we analyzed these cell lines in order to evaluated the presence of CSCs by immunocytochemical analysis, using antibodies against cancer stem cell putative markers (such as CD133, CD44). Hep-2 cell line showed a more marked proliferative activity and tumorigenic capability compared to the other cell lines tested. Moreover, immunocytochemical analysis showed a positive immunoreaction for CD133 and CD44 in all HNSCC cell lines tested, especially in Hep-2 cell line, which was selected for further analysis. Subsequently, cancer specimens of head and neck carcinomas, taken during surgical procedures, were collected and snap-frozen in liquid nitrogen, and primary cultures, obtained from these surgical specimens, were analyzed in order to identify CSCs. Cancer stem cells were enriched through sphere formation, by cultivating HNSCC cells from Hep-2 cell line, derived via HeLa contamination, or primary cultures of HNSCC patients in defined serumfree DMEM/F12 with specific growth factors. Interestingly, after being in culture for 3 weeks, cancer cells gradually started to detach from culture plates, aggregate and form sphere-like bodies. The sphere formation from primary HNSCC culture was faster than that of spheres from Hep-2 cells. To investigate whether these CSC-enriched populations possessed stem cell features, we analyzed the expression of various stem cell-related molecules. Compared with parental cells, CSC-enriched populations showed a markedly increased expression of stem cell markers, including CD133, CD44, Oct4, Sox2, Nanog and Nestin. Consistent with the results of Real-Time PCR, immunocytochemical analysis confirmed the higher expression of CD133 and CD44 in CSC-enriched populations compared with parental cells. To further characterize CSC-enriched populations in HNSCC, we investigated their tumor formation potential in vivo. Both CSC-enriched populations and Hep-2 cells were injected subcutaneously on the left and right backs of immunocompromised mice, and tumor growth was monitored by measurement of tumor mass. Interestingly, athymic mice inoculated with CSC-enriched populations showed a significant increase in tumor growth compared with mice inoculated with parental cells, indicating that CSC-enriched populations may contribute to the malignancy of HNSCC. Mice were then sacrificed and tumor masses were analyzed by Real-Time PCR, and histological and immunohistochemical analyses. Our results showed a significant upregulation of putative stem cell markers on tumor formed by CSC-enriched populations compared with tumor observed after injection of parental cells, at both the RNA and protein levels. These results suggested that CSC-enriched populations exhibited an enhanced ability to form tumor in vivo compared to the parental cell line.

In the present work, we also focused on the expression of the enzyme Nicotinamide $\mathrm{N}$-Methyltransferase, which catalyzed the $\mathrm{N}$-methylation of nicotinamide, pyridines, and other structural analogs, playing a fundamental role in the biotransformation of many xenobiotics [45, 46]. An enhanced expression of NNMT has been reported in a number of cancers, such as glioblastoma [47], stomach adenocarcinoma [48, 49], papillary thyroid cancers [50,51], renal [52,53], and oral squamous cell carcinomas [54-56], colorectal cancer [57], bladder [58], lung and pancreatic cancers [59-61]. In our previous works, we explored NNMT expression in renal cell carcinoma (ccRCC) [52], oral squamous cell carcinoma (OSCC) [54-56], urothelial carcinoma (UC) of the bladder [58] and non-small cell lung cancer (NSCLC) [60]. Although several cancers have been associated with abnormal NNMT expression, its role in cancer cell metabolism remains largely unknown. We previously demonstrated that downregulation of NNMT expression in human oral and lung cancer cell lines significantly inhibited cell growth and tumorigenicity, suggesting that NNMT could play a critical role in the proliferation and tumorigenic capacity of cancer cells, and the possibility of NNMT as a therapeutic target for the treatment of tumor [62-64]. In this work, since CSCs appear to be responsible for tumor initiation and progression (for tumor onset, self-renewal/ maintenance, and metastasis), we decided to analyze the mRNA expression and catalytic 


\section{Cellular Physiology Cell Physiol Biochem 2015;36:784-798 \\ \begin{tabular}{l|l|l}
\hline DOI: 10.1159/000430138 & C 2015 S. Karger AG, Basel
\end{tabular} \\ \begin{tabular}{l|l} 
and Biochemistry Published online: May 22, 2015 & www.karger.com/cpb
\end{tabular} \\ Pozzi et al: CSC Identification and Characterization in HNSCC}

activity of NNMT in CSCs enriched populations. Our analysis revealed an overexpression of NNMT in CSC-enriched populations compared to parental counterpart. In keeping with the results of Real-Time PCR, the levels of NNMT activity were particularly higher in CSCenriched populations than in parental cells. Considering the fundamental role of CSCs in the carcinogenesis and onset of metastases, our results can suggest an interesting role of NNMT in cancer cell metabolism, and the possibility to use its inhibition as a molecular approach in the treatment of cancer.

In the present study, a modified culture system was able to identify and enrich CSCs from HNSCC through sphere formation. A detailed gene expression analysis and in vivo tumorigenicity assay led to a characterization of molecular properties and tumorigenic potential of CSCs, improving our understanding of the fundamental questions underlying cancer stem cell biology in HNSCCs. In this regard, the current knowledge is poor, especially as concerns aspects related to the identification of CSCs in HNSCC and the effectiveness of specific anticancer targeted therapies against CSCs. In this light, our work may help to investigate the etiopathogenetic role of CSCs in HNSCC, evaluating their phenotypic and molecular features. Results obtained by in vitro and in vivo analyses, coupled with clinical data could have the potential to lead to the development of new strategies for head and neck cancer treatment. The discovery of mechanisms leading CSC self-renewal is crucial to identify molecular targets for therapies that are selectively effective against CSC. The possibility to correlate the stem genesis of tumors with the traditional prognostic factors could lead to verify the possible role of stem cell origin as an independent factor for evaluation of the clinical behaviour of these tumors. At the same time, the possibility to identify and characterize specific HNSCC cancer stem cells susceptibility give insights regarding future potential new models of gene therapy throughout gene silencing technique targeting CSCs. These may have direct implications in improving treatment efficacy of HNSCC patients.

\section{Conclusions}

Although further studies are necessary to characterize the function of CSCs in HNSCC and to clarify their specific role in cancer development, our work could represent an useful procedure for cancer stem cell identification and enrichment in HNSCC. These results could lead to the possibility to study optimally CSCs, characterizing their role in head and neck cancerogenesis. In addition, data reported in this study may also have relevant implications for early diagnosis of HNSCC and for the development of a CSC-based cancer therapy.

\section{Acknowledgements}

This work was supported by the Italian Ministry for University and Scientific Research through PRIN 2008 (20089E83YR_004).

\section{References}

1 Argiris A, Karamouzis MV, Raben D, Ferris RL: Head and neck cancer. Lancet 2008;371:1695-1709.

2 Blagosklonny MV: Why therapeutic response may not prolong the life of a cancer patient: selection for oncogenic resistance. Cell Cycle 2005;4:1693-1698.

3 Yamano Y, Uzawa K, Saito K, Nakashima D, Kasamatsu A, Koike H, Kouzu Y, Shinozuka K, Nakatani K, Negoro K, Fujita S, Tanzawa H: Identification of cisplatin-resistance related genes in head and neck squamous cell carcinoma. Int J Cancer 2010;126:437-449.

4 Clarke MF, Fuller M: Stem cells and cancer: two faces of eve. Cell 2006;124:1111-1115.

5 Cho RW, Clarke MF: Recent advances in cancer stem cells. Curr Opin Genet Dev 2008;18:48-53. 


\section{Cellular Physiology Cell Physiol Biochem 2015;36:784-798 \begin{tabular}{l|l|l}
\hline DOI: 10.1159/000430138 & (C) 2015 S. Karger AG, Basel
\end{tabular} \\ \begin{tabular}{l|l} 
Published online: May 22, 2015 & www.karger.com/cpb \\
\hline
\end{tabular} \\ Pozzi et al: CSC Identification and Characterization in HNSCC}

$6 \quad$ Ailles L, Prince M: Cancer stem cells in head and neck squamous cell carcinoma. Methods Mol Biol 2009;568:175-193.

7 Dean M, Fojo T, Bates S: Tumour stem cells and drug resistance. Nat Rev Cancer 2005;5:275-284. review.

$8 \quad$ Jordan CT, Guzman ML, Noble M: Cancer stem cells. N Engl J Med 2006;355:1253-1261.

9 Dalerba P, Cho RW, Clarke MF: Cancer stem cells: models and concepts. Annu Rev Med 2007;58:267-284.

10 Pardal R, Clarke MF, Morrison SJ: Applying the principles of stem-cell biology to cancer. Nat Rev Cancer 2003;3:895-902.

11 Tirino V, Desiderio V, d'Aquino R, De Francesco F, Pirozzi G, Graziano A, Galderisi U, Cavaliere C, De Rosa A, Papaccio G, Giordano A: Detection and characterization of CD133+ cancer stem cells in human solid tumours. PLoS One 2008;3:e3469.

12 Kelly SE, Di Benedetto A, Greco A, Howard CM, Sollars VE, Primerano DA, Valluri JV, Claudio PP: Rapid selection and proliferation of CD133+ cells from cancer cell lines: chemotherapeutic implications. PLoS One 2010;5:e10035.

13 Lapidot T, Sirard C, Vormoor J, Murdoch B, Hoang T, Caceres-Cortes J, Minden M, Paterson B, Caligiuri MA, Dick JE: A cell initiating human acute myeloid leukaemia after transplantation into SCID mice. Nature 1994;367:645-648.

14 Bonnet D, Dick JE: Human acute myeloid leukemia is organized as a hierarchy that originates from a primitive hematopoietic cell. Nat Med 1997;3:730-737.

15 Al-Hajj M, Wicha MS, Benito-Hernandez A, Morrison SJ, Clarke MF: Prospective identification of tumorigenic breast cancer cells. Proc Natl Acad Sci U S A 2003;100:3983-3988.

16 Ponti D, Zaffaroni N, Capelli C, Daidone MG: Breast cancer stem cells: an overview. Eur J Cancer 2006;42:1219-1224.

17 Singh SK, Clarke ID, Terasaki M, Bonn VE, Hawkins C, Squire J, Dirks PB: Identification of a cancer stem cell in human brain tumors. Cancer Res 2003;63:5821-5828.

18 Bao S, Wu Q, McLendon RE, Hao Y, Shi Q, Hjelmeland AB, Dewhirst MW, Bigner DD, Rich JN: Glioma stem cells promote radioresistance by preferential activation of the DNA damage response. Nature 2006;444:756-760.

19 Ho MM, Ng AV, Lam S, Hung JY: Side population in human lung cancer cell lines and tumors is enriched with stem-like cancer cells. Cancer Res 2007;67:4827-4833.

20 Kim CF, Jackson EL, Woolfenden AE, Lawrence S, Babar I, Vogel S, Crowley D, Bronson RT, Jacks T: Identification of bronchioalveolar stem cells in normal lung and lung cancer. Cell 2005;121:823-835.

21 Collins AT, Berry PA, Hyde C, Stower MJ, Maitland NJ: Prospective identification of tumorigenic prostate cancer stem cells. Cancer Res 2005;65:10946-10951.

22 O'Brien CA, Pollett A, Gallinger S, Dick JE: A human colon cancer cell capable of initiating tumour growth in immunodeficient mice. Nature 2007;445:106-110.

23 Dalerba P, Dylla SJ, Park IK, Liu R, Wang X, Cho RW, Hoey T, Gurney A, Huang EH, Simeone DM, Shelton AA, Parmiani G, Castelli C, Clarke MF: Phenotypic characterization of human colorectal cancer stem cells. Proc Natl Acad Sci U S A 2007;104:10158-10163.

24 Hermann PC, Huber SL, Herrler T, Aicher A, Ellwart JW, Guba M, Bruns CJ, Heeschen C: Distinct populations of cancer stem cells determine tumor growth and metastatic activity in human pancreatic cancer. Cell Stem Cell 2007;1:313-323.

25 Yang ZF, Ho DW, Ng MN, Lau CK, Yu WC, Ngai P, Chu PW, Lam CT, Poon RT, Fan ST: Significance of CD90+ Cancer Stem Cells In Human Liver Cancer. Cancer Cell 2008;13:153-166.

26 Prince ME, Sivanandan R, Kaczorowski A, Wolf GT, Kaplan MJ, Dalerba P, Weissman IL, Clarke MF, Ailles LE: Identification of a subpopulation of cells with cancer stem cell properties in head and neck squamous cell carcinoma. Proc Natl Acad Sci U S A 2007;104:973-978.

27 Wei XD, Zhou L, Cheng L, Tian J, Jiang JJ, Maccallum J: In vivo investigation of CD133 as a putative marker of cancer stem cells in Hep-2 cell line. Head Neck 2009;31:94-101.

28 Zhang Q, Shi S, Yen Y, Brown J, Ta JQ, Le AD: A subpopulation of CD133(+) cancer stem-like cells characterized in human oral squamous cell carcinoma confer resistance to chemotherapy. Cancer Lett 2010;289:151-160.

29 Chiou SH, Yu CC, Huang CY, Lin SC, Liu CJ, Tsai TH, Chou SH, Chien CS, Ku HH, Lo JF: Positive correlations of Oct-4 and Nanog in oral cancer stem-like cells and high-grade oral squamous cell carcinoma. Clin Cancer Res 2008;14:4085-4095. 


\section{Cellular Physiology Cell Physiol Biochem 2015;36:784-798 \begin{tabular}{l|l|l}
\hline DOI: 10.1159/000430138 & (C)15 S. Karger AG, Basel
\end{tabular} and Biochemistry Published online: May 22, $2015 \quad$ www.karger.com/cpb \\ Pozzi et al: CSC Identification and Characterization in HNSCC}

30 Lee J, Kotliarova S, Kotliarov Y, Li A, Su Q, Donin NM, Pastorino S, Purow BW, Christopher N, Zhang W, Park JK, Fine HA: Tumor stem cells derived from glioblastomas cultured in bFGF and EGF more closely mirror the phenotype and genotype of primary tumors than do serum-cultured cell lines. Cancer Cell 2006;9:391403.

31 Zhong Y, Guan K, Guo S, Zhou C, Wang D, Ma W, Zhang Y, Li C, Zhang S: Spheres derived from the human SKRC-42 renal cell carcinoma cell line are enriched in cancer stem cells. Cancer Lett 2010;299:150-160.

32 Balducci E, Orsomando G, Polzonetti V, Vita A, Emanuelli M, Raffaelli N, Ruggieri S, Magni G, Natalini P: NMN adenylyltransferase from bull testis: purification and properties. Biochem J 1995;310:395-400

33 Monroe MM, Anderson EC, Clayburgh DR, Wong MH: Cancer stem cells in head and neck squamous cell carcinoma. J Oncol 2011;2011:762780.

34 Lippman SM, Sudbo J, Hong WK: Oral cancer prevention and the evolution of molecular-targeted drug development. J Clin Oncol 2005;23:346-356.

35 Le Tourneau C: Molecularly targeted therapy in head and neck cancer. Bull Cancer 2010;97:1453-1466.

36 Graziano A, D'Aquino R, Tirino V, Desiderio V, Rossi A, Pirozzi G: The stem cell hypothesis in head and neck cancer. J Cell Biochem 2008;103:408-412.

37 Chinn SB, Darr OA, Peters RD, Prince ME: The role of head and neck squamous cell carcinoma cancer stem cells in tumorigenesis, metastasis, and treatment failure. Front Endocrinol 2012;3:90.

38 Zhang Z, Filho MS, Nör JE: The biology of head and neck cancer stem cells. Oral Oncol 2012;48:1-9.

39 Singh SK, Hawkins C, Clarke ID, Squire JA, Bayani J, Hide T, Henkelman RM, Cusimano MD, Dirks PB: Identification of human brain tumour initiating cells. Nature 2004;432:396-401.

40 He QZ, Luo XZ, Wang K, Zhou Q Ao H, Yang Y, Li SX, Li Y, Zhu HT, Duan T: Isolation and characterization of cancer stem cells from high-grade serous ovarian carcinomas. Cell Physiol Biochem 2014;33:173-84.

41 Xu J, Fan W, Tu XX, Zhang T, Hou ZJ, Guo T, Shu X, Luo X, Liu Y, Peng F, Wang C, Xu L, Zhou H, Liu Q: Neural ganglioside GD2 (+) cells define a subpopulation of mesenchymal stem cells in adult murine bone marrow. Cell Physiol Biochem 2013;32:889-98.

42 Zhou L, Wei X, Cheng L, Tian J, Jiang JJ: CD133, one of the markers of cancer stem cells in Hep-2 cell line. Laryngoscope 2007;117:455-460.

43 Pries R, Witrkopf N, Trenkle T, Nitsch SM, Wollenberg B: Potential stem cell marker CD44 is constitutively expressed in permanent cell lines of head and neck cancer. In Vivo 2008;22:89-92.

44 Wang SJ, Wong G, de Heer AM, Xia W, Bourguignon LY: CD44 variant isoforms in head and neck squamous cell carcinoma progression. Laryngoscope 2009;119:1518-1530.

45 Aksoy S, Szumlanski CL, Weinshilboum RM: Human liver nicotinamide N-methyltransferase.cDNA cloning, expression, and biochemical characterization. J Biol Chem 1994;269:14835-14840.

46 Peng Y, Sartini D, Pozzi V, Wilk D, Emanuelli M, Yee VC: Structural basis of substrate recognition in human nicotinamide N-methyltransferase. Biochemistry 2011;50:7800-7808.

47 Markert JM, Fuller CM, Gillespie GY, Bubien JK, McLean LA, Hong RL, Lee K, Gullans SR, Mapstone TB, Benos DJ: Differential gene expression profiling in human brain tumors. Physiol Genomics 2001;5:21-33.

48 Jang JS, Cho HY, Lee YJ, Ha WS, Kim HW: The differential proteome profile of stomach cancer: identification of the biomarker candidates. Oncol Res 2004;14:491-499.

49 Lim BH, Cho BI, Kim YN, Kim JW, Park ST, Lee CW: Overexpression of nicotinamide N-methyltransferase in gastric cancer tissues and its potential post-translational modification. Exp Mol Med 2006;38:455-465.

$50 \mathrm{Xu}$ J, Moatamed F, Caldwell JS, Walker JR, Kraiem Z, Taki K, Brent GA, Hershman JM: Enhanced expression of nicotinamide $\mathrm{N}$-methyltransferase in human papillary thyroid carcinoma cells. J Clin Endocrinol Metab 2003;88:4990-4996.

$51 \mathrm{Xu}$ J, Capezzone M, Xu X, Hershman JM: Activation of nicotinamide N-methyltransferase gene promoter by hepatocyte nuclear factor-1 beta in human papillary thyroid cancer cells. Mol Endocrinol 2005;19:527-539.

52 Sartini D, Muzzonigro G, Milanese G, Pierella F, Rossi V, Emanuelli M: Identification of nicotinamide N-methyltransferase as a novel tumor marker for renal clear cell carcinoma. J Urol 2006;176:2248-2254.

53 Yao M, Tabuchi H, Nagashima Y, Baba M, Nakaigawa N, Ishiguro H, Hamada K, Inayama Y, Kishida T, Hattori K, Yamada-Okabe H, Kubota Y: Gene expression analysis of renal carcinoma: adipose differentiationrelated protein as a potential diagnostic and prognostic biomarker for clear-cell renal carcinoma. J Pathol 2005;205:377-387. 


\section{Cellular Physiology Cell Physiol Biochem 2015;36:784-798 \begin{tabular}{ll|l} 
and & DOI 10.1159/000430138 & $\begin{array}{l}\text { O 2015 S. Karger AG, Basel } \\
\text { www.karger.com/cpb }\end{array}$ \\
\hline
\end{tabular} \\ Pozzi et al: CSC Identification and Characterization in HNSCC}

54 Sartini D, Santarelli A, Rossi V, Goteri G, Rubini C, Ciavarella D, Lo Muzio L, Emanuelli M: Nicotinamide $\mathrm{N}$-methyltransferase upregulation inversely correlates with lymph node metastasis in oral squamous cell carcinoma. Mol Med 2007;13:415-421.

55 Emanuelli M, Santarelli A, Sartini D, Ciavarella D, Rossi V, Pozzi V, Rubini C, Lo Muzio L: Nicotinamide $\mathrm{N}$-Methyltransferase upregulation correlates with tumour differentiation in oral squamous cell carcinoma. Histol Histopathol 2010;25:15-20.

56 Sartini D, Pozzi V, Renzi E, Morganti S, Rocchetti R, Rubini C, Santarelli A, Lo Muzio L, Emanuelli M: Analysis of tissue and salivary nicotinamide N-methyltransferase in oral squamous cell carcinoma: basis for the development of a noninvasive diagnostic test for early-stage disease. Biol Chem 2012;393:505-511.

57 Roessler M, Rollinger W, Palme S, Hagmann ML, Berndt P, Engel AM, Schneidinger B, Pfeffer M, Andres H, Karl J, Bodenmüller H, Rüschoff J, Henkel T, Rohr G, Rossol S, Rösch W, Langen H, Zolg W, Tacke M: Identification of nicotinamide N-methyltransferase as a novel serum tumor marker for colorectal cancer. Clin Cancer Res 2005;11:6550-6557.

58 Sartini D, Muzzonigro G, Milanese G, Pozzi V, Vici A, Morganti S, Rossi V, Mazzucchelli R, Montironi R, Emanuelli M: Upregulation of Tissue and Urinary Nicotinamide N-Methyltransferase in Bladder Cancer: Potential for the Development of a Urine-Based Diagnostic Test. Cell Biochem Biophys 2012;65:473-483.

59 Tomida M, Mikami I, Takeuchi S, Nishimura H, Akiyama H: Serum levels of nicotinamide N-methyltransferase in patients with lung cancer. J Cancer Res Clin Oncol 2009;135:1223-1229.

60 Sartini D, Morganti S, Guidi E, Rubini C, Zizzi A, Giuliante R, Pozzi V, Emanuelli M: Nicotinamide N-methyltransferase in Non-small Cell Lung Cancer: Promising Results for Targeted Anti-cancer Therapy. Cell Biochem Biophys 2013 Mar 27;67:865-873.

61 Rogers CD, Fukushima N, Sato N, Shi C, Prasad N, Hustinx SR, Matsubayashi H, Canto M, Eshleman JR, Hruban RH, Goggins M: Differentiating pancreatic lesions by microarray and QPCR analysis of pancreatic juice RNAs. Cancer Biol Ther 2006;5:1383-1389.

62 Pozzi V, Mazzotta M, Lo Muzio L, Sartini D, Santarelli A, Renzi E, Rocchetti R, Tomasetti M, Ciavarella D, Emanuelli M: Inhibiting proliferation in KB cancer cells by RNA interference-mediated knockdown of nicotinamide N-methyltransferase expression. Int J Immunopathol Pharmacol 2011;24:69-77.

63 Pozzi V, Sartini D, Morganti S, Giuliante R, Di Ruscio G, Santarelli A, Rocchetti R, Rubini C, Tomasetti M, Giannatempo G, Orlando F, Provinciali M, Lo Muzio L, Emanuelli M: RNA-mediated gene silencing of nicotinamide $\mathrm{N}$-methyltransferase is associated with decreased tumorigenicity in human oral carcinoma cells. PLoS One 2013;8:e71272.

64 Sartini D, Seta R, Pozzi V, Morganti S, Rubini C, Zizzi A, Tomasetti M, Santarelli L, Emanuelli M: Role of nicotinamide N-methyltransferase in non-small cell lung cancer: in vitro effect of shRNA-mediated gene silencing on tumourigenicity. Biol Chem 2015;396:225-234. 